\title{
Optimal Media for In-Vitro Regeneration of Two Local Genotypes of Chili Pepper (Capsicum annuum L.) from West Sumatera
}

\author{
Renfiyeni $^{*}$, Lily Syukriani ${ }^{*}$, Alfi Asben $^{\$}$, and Jamsari Jamsari ${ }^{@}$ \\ ${ }^{\#}$ Agricultural Faculty, Mahaputra Muhammad Yamin University, Solok, West Sumatera, Indonesia \\ E-mail: renfiyeni@yahoo.com \\ *Plant Breeding Department, Agricultural Faculty, Andalas University, 25136-Padang West Sumatera, Indonesia \\ E-mail: syukriani2011@yahoo.com \\ ${ }^{\$}$ Agricultural Technology Department, Agricultural Technology Faculty, 25136-Andalas University, Padang West Sumatera, Indonesia \\ E-mail: alfi_asben@yahoo.com \\ ${ }^{\circledR}$ Biotechnological Laboratory, Agricultural Faculty, Andalas University, 25136-Padang West Sumatera, Indonesia \\ E-mail:ajamsari@yahoo.com.
}

\begin{abstract}
Genetic engineering strategy in chilli peppers (Capsicum annuum L.) has been applied so far to improve its genetic capacity for instance against some important diseases. This strategy needs an established system for calli preparation as well as transformant regeneration. In most cases, this necessity is genotype dependent especially for some local genotypes. Based on this, we optimized media for calli induction, shoot and root regeneration of our three local cultivars namely Kampung, Kopay, and Trisula. Media combinations basically were composed of MS and combined with some growth factors, for instance, IAA, BAP, NAA and TDZ with different combinations for each calli induction, shoot and root regeneration. All media compositions were supplemented with 30 $\mathrm{g} / \mathrm{L}$ sucroses. The best medium for calli induction was MS media supplemented with $4 \mathrm{mg} / \mathrm{L} \mathrm{BAP,} 0.5 \mathrm{mg} / \mathrm{L} \mathrm{IAA}$ and L2 vitamin (Thiamin-HCl and Pyrodoxine-HCl). While the best medium for shoot induction and elongation was MS supplemented with $1 \mathrm{mg} / \mathrm{L}$ $\mathrm{BAP}, 5 \mathrm{mg} / \mathrm{L} \mathrm{AgNO} \mathrm{Al}_{3}, 2 \mathrm{mg} / \mathrm{L} \mathrm{GA}_{3}, 2 \mathrm{mg} / \mathrm{L}$ Calcium Pantothenate and $\mathrm{L} 2$ vitamin. Furthermore, the best medium for root induction and elongation was WPM (Woody Plant Medium) supplemented with $0.4 \mathrm{mg} / \mathrm{L} \mathrm{NAA}$. This finding should provide optimal media for calli induction and shoot-root regeneration for the three local cultivars Kampung, Kopay, and Trisula.
\end{abstract}

Keywords - calli induction; shoot and root induction; Capsicum annuum; genetic transformation; local genotype

\section{INTRODUCTION}

Chili pepper is an important vegetable crop, because of its content of high concentration of vitamin A and C. This species commonly used as mixing component in foods and drugs especially in Asia and Pacific. Described by [1] that chili pepper contains useful chemical compounds, including volatile oil, fat, capsaicinoid, carotenoid, vitamin, protein, fiber, and minerals. Pepper sprays containing capsicum oleoresin provide ingredients for a non-lethal deterrent or repellent to some human and animal behavior [2] and are useful riot control agents and self-defense tools. Chilies also have antifungal property against fungal species belonging to Aspergillus and Fusarium [3]-[4].

Cultivar development of chili pepper in some regions for some particular reason, for instance, genetic resistance improvement is basically generated from local genotypes.
During that phase of genetic improvement especially via genetic engineering, the availability of genetically identical clones and its downstream regeneration system is an absolute prerequisite. This will be only feasible to be achieved via tissue culture technique approach. However, in most cases, many of tissue culture technique are genotype dependent. For that reason, local cultivar development always needs any specific treatment such as the establishment of calli induction and its downstream regeneration.

Three chili pepper cultivars namely Kopay, Kampung, and Trisula are the most popular cultivars used in chili pepper cultivation in West Sumatera. Kopay and Kampung have been known as local cultivar bred by local farmer since 2013. The Kopay cultivar is characterized by its longer fruit that can reach up to $35 \mathrm{~cm}$ in length, while the Kampung cultivar is characterized by its unique taste, quite spicy, high preference, and long-term storage capacity. The Trisula 
cultivar is known as commercial cultivar mainly grown by the farmer in this region for its special characters, for instance, high uniformity, relatively short age, quite spicy, long-term storage, and high productivity (17-20 ton/ha). Unfortunately, the three cultivars are not resistant to many viruses causing diseases such as Pepper Yellow leaf Curl Virus which are commonly infecting almost all chili pepper cultivated in West Sumatera [5]-[6].

Our preliminary study indicated that all those three mentioned chili pepper cultivars are difficult to be genetically engineered. This is regarded as the main problem particularly of their regeneration system after transformation step, although some successful regeneration system of nontransgenic chili pepper has ever been reported by some authors [7]. In vitro regeneration can be difficult to be achieved for some plant species or particular genotypes within a species [8]. Scientific publication dealing with genetic engineering of red chili pepper in scientific journals which is especially reporting in vitro regeneration is scarce. So far, most of the scientific publications are mainly dominated by sweet pepper [9]. This fact led to a general conclusion on genotype dependent phenomenon in tissue culture technique. Based on this reason, investigating of regeneration system particularly for some specific and local interesting genotypes of chili pepper is expected could accelerate cultivar development of chilli pepper resistant.

We described here the establishing of chili pepper regeneration system of three local cultivars mainly cultivated in West Sumatera. This, in turn, should be an important step for establishing an efficient and stable regeneration system in our local chili pepper.

\section{MATERIAL AND METHOD}

\section{A. Red-Chili Pepper Genotypes and Seed Germination}

We used three local red chili pepper genotypes namely Kopay, Kampung, and Trisula as described by [10]. Seed surface was sterilized by serial sterilization using $20 \%$ Chlorox, followed by three times washing for 10 minutes, rinsed with sterilized aqua dest for three times, and germinated in vitro on MS basal medium. The seedling was kept for 24 days before used.

\section{B. Calli Induction}

Similar treatment for calli induction including genotypes as well as the medium was performed as described by [10] in the previous study. Chili seeds were germinated for 24 days in the jam bottle under 800-1,000 lux light condition. Seedlings were removed from the bottle and subsequently each part of the first leaf, cotyledon, hypocotyls, and epicotyls were used as explant. Each explant was cultured in MS medium, completed with 2,4D, IAA, and BAP, NAA, IBA, Kinetin, TDZ depending on the combination applied (see Table 1) and supplemented with $30 \mathrm{~g} / \mathrm{L}$ sucrose and 8 $\mathrm{g} / \mathrm{L}$ agar at $\mathrm{pH}$ 5.8. The explants were kept in 800-1000 lux of light intensity and maintained at $22^{\circ} \mathrm{C}$.

\section{Shoot Regeneration}

In total 23 medium combinations, which were basically composed of MS basal medium and completed with BAP, TDZ, IAA, NAA, GA3, L2 vitamin (Thiamine-HCl and pyridoxine- $\mathrm{HCl}), \mathrm{AgNO} 3$, and Calcium Pantothenate supplemented with $30 \mathrm{gL}^{-1}$ sucrose, was used for shoot regeneration. All medium was set at a $\mathrm{pH}$ value of 5.8 (Table 2). Calli were transferred into shoot regeneration medium after 14 days. The primordial shot was further moved to medium for shoot regeneration.

TABLE I

MEDIUM COMBINATION USED FOR CALLI INDUCTION

\begin{tabular}{|c|c|c|}
\hline Media & $\begin{array}{l}\text { Media Combination } \\
\end{array}$ & References \\
\hline $\mathrm{A}$ & $\mathrm{MS}+\mathrm{NAA} 10 \mathrm{mg} / \mathrm{L}$ & {$[10]$} \\
\hline B & $\mathrm{MS}+\mathrm{NAA} 4 \mathrm{mg} / \mathrm{L}$ & [10] \\
\hline $\mathrm{C}$ & $\begin{array}{l}\mathrm{MS}+2,4 \text { D } 1,5 \mathrm{mg} / \mathrm{L}+\text { kinetin } 0,5 \\
\mathrm{mg} / \mathrm{L}\end{array}$ & [10] \\
\hline $\mathrm{D}$ & $\mathrm{MS}+2,4 \mathrm{D} 4 \mathrm{mg} / \mathrm{L}$ & {$[10]$} \\
\hline $\mathrm{E}$ & $\mathrm{MS}+2,4 \mathrm{D} 10 \mathrm{mg} / \mathrm{L}+\mathrm{NAA} 4 \mathrm{mg} / \mathrm{L}$ & [10] \\
\hline $\mathrm{F}$ & $\mathrm{MS}+2,4 \mathrm{D} 10 \mathrm{mg} / \mathrm{L}+\mathrm{NAA} 10 \mathrm{mg} / \mathrm{L}$ & {$[10]$} \\
\hline $\mathrm{G}$ & $\mathrm{MS}+2,4 \mathrm{D} 10 \mathrm{mg} / \mathrm{L}+\mathrm{IBA} 10 \mathrm{mg} / \mathrm{L}$ & {$[10]$} \\
\hline $\mathrm{H}$ & $\mathrm{MS}+\mathrm{IAA} 10 \mathrm{mg} / \mathrm{L}+2,4 \mathrm{D} 10 \mathrm{mg} / \mathrm{L}$ & {$[10]$} \\
\hline I & $\mathrm{MS}+\mathrm{TDZ} 2 \mathrm{mg} / \mathrm{L}+\mathrm{NAA} 0.1 \mathrm{mg} / \mathrm{L}$ & [11] \\
\hline $\mathrm{J}$ & $\mathrm{MS}+\mathrm{BAP} 4 \mathrm{mg} / \mathrm{L}+\mathrm{IAA} 0.5 \mathrm{mg} / \mathrm{L}$ & {$[12]$} \\
\hline $\mathrm{K}$ & $\begin{array}{l}\mathrm{MS}+\mathrm{BAP} 4 \mathrm{mg} / \mathrm{L}+\mathrm{IAA} 0.25 \mathrm{mg} / \mathrm{L}+ \\
\text { vitamin L2 }\end{array}$ & {$[10]$} \\
\hline $\mathrm{L}$ & $\begin{array}{l}\text { MS + BAP } 5 \mathrm{mg} / \mathrm{L}+\text { IAA } 0.25 \mathrm{mg} / \mathrm{L}+ \\
\text { vitamin L2 }\end{array}$ & [10] \\
\hline M & $\begin{array}{l}\text { MS + BAP } 6 \text { mg/L + IAA } 0.25 \mathrm{mg} / \mathrm{L}+ \\
\text { vitamin L2 }\end{array}$ & {$[10]$} \\
\hline $\mathrm{N}$ & $\mathrm{MS}+\mathrm{BAP} 5 \mathrm{mg} / \mathrm{L}+\mathrm{IAA} 0.25 \mathrm{mgL}^{-1}$ & {$[10]$} \\
\hline $\mathrm{O}$ & $\mathrm{MS}+\mathrm{BAP} 6 \mathrm{mg} / \mathrm{L}+\mathrm{IAA} 0.25 \mathrm{mg} / \mathrm{L}$ & [10] \\
\hline $\mathrm{P}$ & $\mathrm{MS}+\mathrm{BAP} 5 \mathrm{mg} / \mathrm{L}+\mathrm{NAA} 0.1 \mathrm{mg} / \mathrm{L}$ & {$[13]$} \\
\hline $\mathrm{Q}$ & $\mathrm{MS}+\mathrm{BAP} 4 \mathrm{mg} / \mathrm{L}+$ vitamin L2 & [10] \\
\hline
\end{tabular}

TABLE II

MEDIA USED FOR SHOOT REgENERATION

\begin{tabular}{|c|c|c|}
\hline Media & Media Combination & References \\
\hline A & $\mathrm{MS}+\mathrm{TDZ} 0.5 \mathrm{mg} / \mathrm{L}+\mathrm{BAP} 1 \mathrm{mg} / \mathrm{L}$ & This study \\
\hline B & $\mathrm{MS}+\mathrm{TDZ} 0.5 \mathrm{mg} / \mathrm{L}+\mathrm{BAP} 3 \mathrm{mg} / \mathrm{L}$ & [14] \\
\hline $\mathrm{C}$ & $\mathrm{MS}+\mathrm{TDZ} 0.5 \mathrm{mg} / \mathrm{L}+\mathrm{BAP} 5 \mathrm{mg} / \mathrm{L}$ & This study \\
\hline $\mathrm{D}$ & $\mathrm{MS}+\mathrm{BAP} 0.5 \mathrm{mg} / \mathrm{L}$ & This study \\
\hline $\mathrm{E}$ & $\mathrm{MS}+\mathrm{BAP} 1.0 \mathrm{mg} / \mathrm{L}$ & This study \\
\hline $\mathrm{F}$ & $\mathrm{MS}+\mathrm{BAP} 1.5 \mathrm{mg} / \mathrm{L}$ & This study \\
\hline $\mathrm{G}$ & $\mathrm{MS}+\mathrm{BAP} 2.0 \mathrm{mg} / \mathrm{L}+\mathrm{IAA} 0.5 \mathrm{mg} / \mathrm{L}$ & This study \\
\hline $\mathrm{H}$ & $\mathrm{MS}+\mathrm{BAP} 3.0 \mathrm{mg} / \mathrm{L}+\mathrm{IAA} 0.5 \mathrm{mg} / \mathrm{L}$ & This study \\
\hline $\mathrm{I}$ & $\mathrm{MS}+\mathrm{BAP} 4.0 \mathrm{mg} / \mathrm{L}+\mathrm{IAA} 0.5 \mathrm{mgL}$ & This study \\
\hline $\mathrm{J}$ & $\mathrm{MS}+\mathrm{BAP} 0.5 \mathrm{mg} / \mathrm{L}+\mathrm{GA} 31.0 \mathrm{mg} / \mathrm{L}$ & This study \\
\hline $\mathrm{K}$ & MS + IAA $2.0 \mathrm{mg} / \mathrm{L}+3.0 \mathrm{mg} / \mathrm{L}$ kinetin & This study \\
\hline $\mathrm{L}$ & $\mathrm{MS}+\mathrm{BAP} 5.0 \mathrm{mg} / \mathrm{L}+\mathrm{AgNO}_{3} 3.0 \mathrm{mg} / \mathrm{L}$ & {$[13]$} \\
\hline $\mathrm{M}$ & $\mathrm{MS}+\mathrm{BAP} 3.0 \mathrm{mg} / \mathrm{L}+\mathrm{IAA} 1 \mathrm{mg} / \mathrm{L}$ & This study \\
\hline $\mathrm{N}$ & $\mathrm{MS}+\mathrm{TDZ} 2.0 \mathrm{mg} / \mathrm{L}+\mathrm{NAA} 0.1 \mathrm{mg} / \mathrm{L}$ & {$[11]$} \\
\hline $\mathrm{O}$ & $\mathrm{MS}+\mathrm{BAP} 3.0 \mathrm{mg} / \mathrm{L}$ + NAA $1.0 \mathrm{mg} / \mathrm{L}$ & {$[15]$} \\
\hline $\mathrm{P}$ & $\mathrm{MS}+\mathrm{TDZ} 3.0 \mathrm{mg} / \mathrm{L}+\mathrm{NAA} 1.0 \mathrm{mg} / \mathrm{L}$ & This study \\
\hline $\mathrm{Q}$ & $\mathrm{MS}+\mathrm{BAP} 2.0 \mathrm{mg} / \mathrm{L}+\mathrm{NAA} 0.1 \mathrm{mg} / \mathrm{L}$ & [13] \\
\hline $\mathrm{R}$ & $\mathrm{MS}+\mathrm{TDZ} 0.5 \mathrm{mg} / \mathrm{L}$ & This study \\
\hline $\mathrm{S}$ & $\mathrm{MS}+\mathrm{BAP} 3.0 \mathrm{mg} / \mathrm{L}+\mathrm{IAA} 1.5 \mathrm{mg} / \mathrm{L}$ & This study \\
\hline $\mathrm{T}$ & $\mathrm{MS}+\mathrm{BAP} 0.5 \mathrm{mg} / \mathrm{L}$ & This study \\
\hline $\mathrm{U}$ & $\mathrm{MS}+\mathrm{BAP} 1.0 \mathrm{mg} / \mathrm{L}$ & This study \\
\hline $\mathrm{V}$ & $\mathrm{MS}+\mathrm{BAP} 1.5 \mathrm{mg} / \mathrm{L}$ & This study \\
\hline $\mathrm{W}$ & $\begin{array}{l}\mathrm{MS}+\mathrm{BAP} 1.0 \mathrm{mg} / \mathrm{L}+\mathrm{GA}_{3} 2.0 \mathrm{mg} / \mathrm{L}+ \\
\mathrm{AgNO}_{3} 5.0 \mathrm{mg} / \mathrm{L}+\mathrm{Kalium} \\
\text { Pantothenate } 2.0 \mathrm{mg} / \mathrm{L}+\text { vitamin } \mathrm{L} 2\end{array}$ & {$[12]$} \\
\hline
\end{tabular}

\section{Root Induction}

MS and WPM basal medium were used for root regeneration. These media were combined with IAA, NAA, 
IBA, GA3, and L2 vitamin (Table 3), supplemented with 30 $\mathrm{g} / \mathrm{L}$ sucrose and $8 \mathrm{mg} / \mathrm{L}$ agar, with a $\mathrm{pH}$ value of 5.8 . Eighteen medium combinations in total were used for root regeneration.

TABLE III

MEDIA USED FOR ROOT INDUCTION

\begin{tabular}{|c|c|c|}
\hline Media & Media Combination & References \\
\hline $\mathrm{A}$ & MS + IAA $0.1 \mathrm{mg} / \mathrm{L}$ + L2 vitamin & {$[12]$} \\
\hline $\mathrm{B}$ & $\mathrm{MS}+\mathrm{IAA} 0.75 \mathrm{mg} / \mathrm{L}^{-1}+\mathrm{L} 2$ vitamin & This study \\
\hline $\mathrm{C}$ & $1 / 2 \mathrm{MS}+\mathrm{IBA} 1.0 \mathrm{mg} / \mathrm{L}^{-1}$ & This study \\
\hline $\mathrm{D}$ & $\begin{array}{l}\mathrm{MS}+\mathrm{IBA} 0.05 \mathrm{mg} / \mathrm{L}+\mathrm{NAA} 0.1 \\
\mathrm{mg} / \mathrm{L}\end{array}$ & This study \\
\hline $\mathrm{E}$ & $\mathrm{MS}+\mathrm{IBA} 0.5 \mathrm{mg} / \mathrm{L}$ & This study \\
\hline $\mathrm{F}$ & $\mathrm{MS}+\mathrm{GA} 31.0 \mathrm{mg} / \mathrm{L}$ & This study \\
\hline $\mathrm{G}$ & $\mathrm{MS}+\mathrm{NAA} 1.0 \mathrm{mg} / \mathrm{L}$ & This study \\
\hline $\mathrm{H}$ & MS + IAA $0.05 \mathrm{mg} / \mathrm{L}$ + L2 vitamin & This study \\
\hline $\mathrm{I}$ & MS + IAA $0.15 \mathrm{mg} / \mathrm{L}$ + L2 vitamin & This study \\
\hline $\mathrm{J}$ & $\mathrm{MS}+\mathrm{IBA} 0.05 \mathrm{mg} / \mathrm{L}+\mathrm{L} 2$ vitamin & This study \\
\hline $\mathrm{K}$ & $\mathrm{MS}+\mathrm{IBA} 0.1 \mathrm{mg} / \mathrm{L}$ + L2 vitamin & This study \\
\hline $\mathrm{L}$ & $\mathrm{MS}+\mathrm{IBA} 0.15 \mathrm{mg} / \mathrm{L}$ + L2 vitamin & This study \\
\hline $\mathrm{M}$ & MS + NAA $0.05 \mathrm{mg} / \mathrm{L}$ + L2 vitamin & This study \\
\hline $\mathrm{N}$ & $\begin{array}{l}\mathrm{MS}+\mathrm{IAA} 0.1 \mathrm{mg} / \mathrm{L}+\mathrm{IBA} 0.05 \\
\mathrm{mg} / \mathrm{L}\end{array}$ & This study \\
\hline $\mathrm{O}$ & $\mathrm{MS}+\mathrm{NAA} 0.1 \mathrm{mg} / \mathrm{L}+\mathrm{L} 2$ vitamin & This study \\
\hline $\mathrm{P}$ & $\mathrm{MS}+\mathrm{NAA} 0.15 \mathrm{mg} / \mathrm{L}+\mathrm{L} 2$ vitamin & This study \\
\hline $\mathrm{Q}$ & WPM + NAA $0.2 \mathrm{mg} / \mathrm{L}$ & This study \\
\hline $\mathrm{R}$ & WPM + NAA $0.4 \mathrm{mg} / \mathrm{L}$ & This study \\
\hline
\end{tabular}

\section{E. Data Analysis}

Each treatment in every regeneration steps was completely randomized and performed in 15 replicates. All data obtained were analyzed with analysis of variance (ANNOVA) followed by Duncan Multiple Range Test, with $5 \%$ level of significant.

\section{RESULTS AND DISCUSSION}

\section{F. Effect of Media in Calli Induction}

Two medium combinations (MS+BAP+IAA $+\mathrm{L}_{2}$ Vitamin, and MS+2.4-D) could induce $100 \%$ of calli formation in all three cultivars. Fifteen medium combinations induced calli formation under $100 \%$. Both media $\mathrm{MS}+\mathrm{BAP}+\mathrm{IAA}+\mathrm{L}_{2}$ Vitamin and $\mathrm{MS}+2.4 \mathrm{D}$ showed the best response compared to others. It seemed that both treatments were suitable for calli induction. The concentration of auxin in both medium (BAP $4.0 \mathrm{mg} / \mathrm{L}$, IAA, $5.0 \mathrm{mg} / \mathrm{L}$ and $2.4-\mathrm{D} 4.0 \mathrm{mg} / \mathrm{L}$ ) is regarded as optimum for enzyme activation to promote calli induction. The combination of BAP and IAA with appropriate concentration could improve calli induction. This result matched with previously reported in [12]. She found $100 \%$ calli induction by using a combination of $\mathrm{MS}+\mathrm{BAP}+\mathrm{IAA}+\mathrm{L} 2$ vitamin. MS medium supplemented with 2,4-D (1.0 mg/L) and BAP $(2.0 \mathrm{mg} / \mathrm{L})$ is the best medium to obtain an efficient callogenesis in genotypes of $C$. annuиm L [16]. However reported by [13] that the best medium for calli induction was a combination with BAP 5 $\mathrm{mg} / \mathrm{L}$, with NAA $0.1 \mathrm{mg} / \mathrm{L}$ for hypocotyl. He could get $95 \%$ of calli formation while a combination of BAP $5.0 \mathrm{mg} / \mathrm{L}$ and IAA $1.0 \mathrm{mg} / \mathrm{L}$ (for cotyledon) could produce only $80 \%$ of calli.
Table 4 showed that MS+2,4-D could induce calli faster (3.5 days) compared to another medium ( $>4$ days). This ability is presumably caused by the presence of 2,4-D. However, [15] found different results. They found that MS supplemented with $1.5 \mathrm{mg} / \mathrm{L}$ 2,4-D required 6-8 days to induce calli from two chili pepper varieties, Nepali and NARC-IV. Our results showed that MS combined with 2,4 $\mathrm{D}$ could effectively induce callus formation in our local genotypes. Reported by [13] that the fastest calli initiation from cotyledon could achieve just 15 days after being treated with $\mathrm{MS}+5.0 \mathrm{mg} / \mathrm{L} \mathrm{BAP}+3.0 \mathrm{mg} / \mathrm{L} \mathrm{AgNO}_{3}$ while hypocotyl could initiate just 17 days after treatment. Another combination of MS for instance with $5.0 \mathrm{mg} / \mathrm{L} \mathrm{BAP}+0.1$ mg/L NAA initiated calli induction of cotyledon after 18 days.

TABLE IV

EFFECT OF MEDIUM ON DAYS OF GROWING CALLI

\begin{tabular}{|c|c|}
\hline Media & Mean \pm SD \\
\hline A & $5.33 \pm 0.77$ A \\
\hline B & $5.18 \pm 0.83$ A \\
\hline C & $5.17 \pm 0.44$ A \\
\hline D & $5.17 \pm 0.94$ A \\
\hline E & $5.17 \pm 0.85 \mathrm{~A}$ \\
\hline F & $5.17 \pm 0.63 \mathrm{~A}$ \\
\hline G & $5.17 \pm 0.62 \mathrm{~A}$ \\
\hline H & $5.17 \pm 0.76 \mathrm{~A}$ \\
\hline I & $5.08 \pm 0.67 \mathrm{~A}$ \\
\hline J & $4.83 \pm 0.80 \mathrm{AB}$ \\
\hline K & $4.75 \pm 0.77 \mathrm{AB}$ \\
\hline $\mathrm{L}$ & $4.58 \pm 0.35 \mathrm{AB}$ \\
\hline $\mathrm{M}$ & $4.58 \pm 0.39 \mathrm{AB}$ \\
\hline $\mathrm{N}$ & $4.58 \pm 0.56 \mathrm{AB}$ \\
\hline $\mathrm{O}$ & $4.42 \pm 0.40 \mathrm{ABC}$ \\
\hline $\mathrm{P}$ & $4.08 \pm 0.45 \quad \mathrm{BC}$ \\
\hline $\mathrm{Q}$ & $3.50 \pm 0.52$ \\
\hline
\end{tabular}

Mean followed by the same letters were not significantly different $(\mathrm{p}=$ $0.05)$.

The role of 2,4-D has been well known in promoting calli induction. For instance, [15] found $1.5 \mathrm{mg} / \mathrm{L}$ of $2.4-\mathrm{D}$, could induce calli formation of two varieties Nepali and NARC-IV faster. Described by [17] that the optimum concentration of 2,4-D provided maximum calli growth because it induces DNA and RNA synthesis in the cell. Effect of 2,4-D also described by [18] that control synthesis and metabolism of IAA and cytokinins in cells and thus, in turn, regulate calli induction.

Further investigation showed that each medium showed a different effect on color and texture of calli. MS contained BAP, IAA, and L2 vitamin produced yellowish and green calli with compact texture, while MS contained 2,4 D produced yellowish white calli with crumb texture. Furthermore, the size of calli showed different performance. Generally, calli induced in MS medium $+2.4 \mathrm{D}$ were relatively higher than that callus induced in $\mathrm{MS}+B A P+$ $I A A+\mathrm{L} 2$ Vitamin (data not shown). Some earlier reports of in vitro studies in Capsicum also reported the effectiveness of BAP in combination with IAA in inducing multiple shoot buds in chili tissue cultures and results also suggest the same. MS medium containing Kin alone was found to be the least effective among the three cytokinins (BAP, Zea, and Kin) tested and was not used for further studies [19]. 


\section{G. Effect of Genotype on Calli Induction}

The three cultivars investigated in this study showed a different response, with respect to calli induction. Data analysis was shown in Table 5. Kampung cultivar showed the fastest period in calli induction compared to the other two other cultivars. However, this cultivar did not differentiate significantly with Kopay.

TABLE V

EFFECT OF GENOTYPE ON DAYS OF GROWING CALLI

\begin{tabular}{|c|c|}
\hline Genotype & Mean \pm SD \\
\hline Trisula & $5.10 \pm 0.5 \quad \mathrm{~A}$ \\
\hline Kopay & $4.77 \pm 0.62 \quad B$ \\
\hline Kampung & $4.59 \pm 0.62 \quad B$ \\
\hline
\end{tabular}

In general Kampung cultivar showed a good response to all medium and type of explant. Kampung cultivar needed only 4.59 days for calli induction, while Kopay and Trisula needed 4.77 , and 5.1 days respectively. Some modification of in-vitro protocol must be applied for regeneration of varieties of chilli pepper cultivars. This factor plays a major effect, especially in explants regeneration. Optimal protocol for in-vitro propagation for specific cultivars was necessary to perform. The genotype, type of explant, and media composition were three major factors determine the success of plant regeneration in vitro [8].

\section{H. Influence of Explants Source on Calli Induction}

The response of five explants sources i.e., first leaf, cotyledon, hypocotyl, and epicotyl were investigated in this study. Data analysis is shown in Table 6. The first leaf showed fastest calli induction, followed by epicotyl, hypocotyls, and cotyledons, respectively. It seemed that young tissue was relatively easy to produce calli. Cells of young tissue normally still actively divide and differentiate. However, [20] found that shoot tips [21] leaf, stem, hypocotyls, cotyledonary leaves, root, shoot tip and embryo [9] induced somatic embryogenesis of some chili pepper cultivars could be regenerated effectively.

TABLE VI

INFLUENCE OF EXPLANT SOURCE ON DAYS OF GROWING CALLI

\begin{tabular}{|l|l|}
\hline Explant & Mean \pm SD \\
\hline Hypocotyl & $5.29 \pm 1.11$ A \\
\hline Cotiledone & $5.00 \pm 1.14 \quad$ B \\
\hline Epicotyl & $4.53 \pm 0.91 \quad$ C \\
\hline First leaf & $4.45 \pm 0.92 \quad$ C \\
\hline
\end{tabular}

Mean followed by the same letters were not significantly different $(\mathrm{p}=0.05)$

Microscopic observation showed that calli grown in MS medium+BAP+IAA+L2 Vitamin likely could produce buds (data not shown). They showed complete developmental phase or organogenic characteristic, i.e. the formation of globular, heart, torpedo and cotyledonary phase (Fig. 1). On the other hand, calli grown on MS+2.4D did not show organogenic characteristic, i.e. calli failed to undergo globular, heart, torpedo, and cotyledonary phase. According to [22] MS medium containing BAP 3-7 mg/mL and NAA $1.0 \mathrm{mg} / \mathrm{mL}$ could be used to induce calli growth of young leaf explants, hypocotyl, and chili root tip cv Stadium, Sudra, and Chile 109, but they grew very slow and did not produce embryogenic.

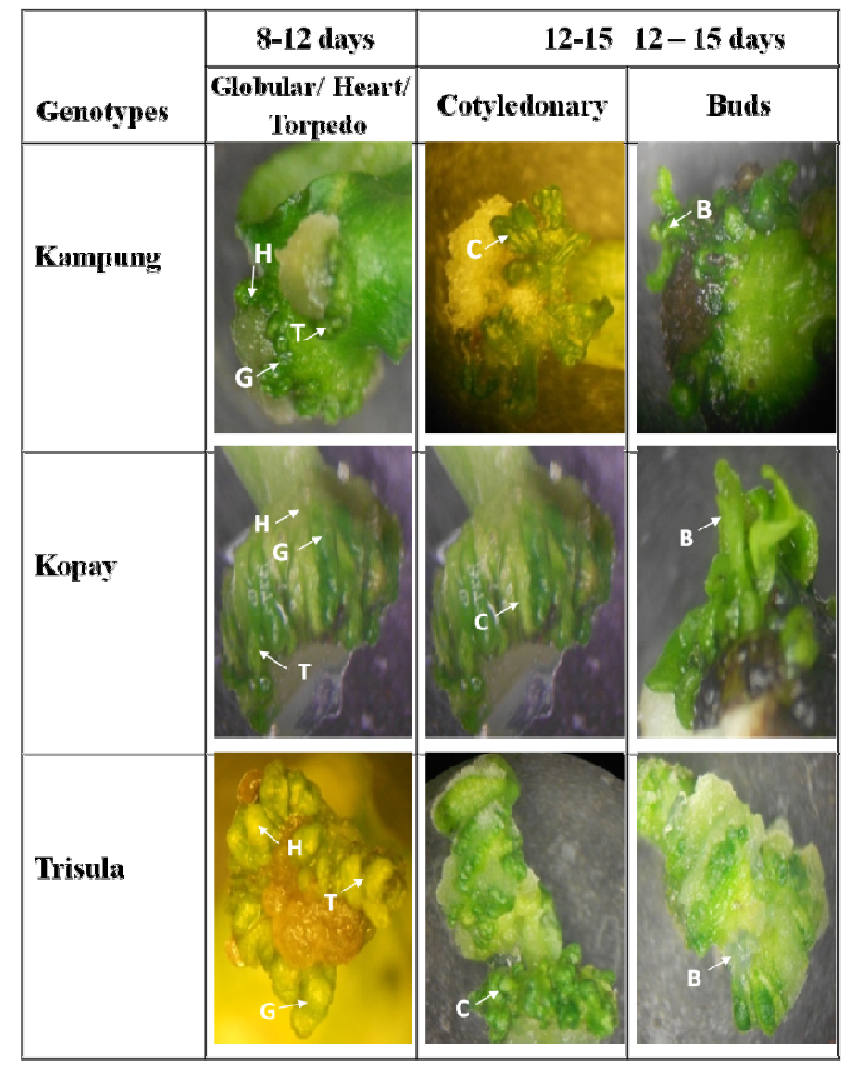

Fig. 1 Developmental phase of calli grown in $\mathrm{MS}+\mathrm{BAP}+\mathrm{IAA}+\mathrm{L}$ Vitamin. Each representative developmental phase is shown by an arrowhead. $\mathrm{G}=$ globular phase, $\mathrm{H}=$ Heart shape, $\mathrm{T}=$ Torpedo, $\mathrm{C}=$ Cotyledonary, and $\mathrm{B}=$ Buds

$\mathrm{MS}+\mathrm{BAP}+\mathrm{IAA}+\mathrm{L} 2$ vitamin produced organogenic calli. Fig. 1 showed that response of three genotypes was relatively similar with $\mathrm{MS}+\mathrm{BAP}+\mathrm{IAA}+\mathrm{L} 2$ vitamin on the growth of calli. Buds were formed at 8-15 days in induction medium. This study showed different results with previously study described by [12], where MS+BAP and IAA + Vitamin L2 could produce shoots directly from calli in all thirteen genotypes of chili pepper she tested.

\section{Shoot Induction}

One out of 23 media used for shoot regeneration could successfully induce shoot formation directly from callus. The medium contained MS+BAP $1 \mathrm{mg} / \mathrm{L}+\mathrm{GA} 32.0$ $\mathrm{mg} / \mathrm{L}+\mathrm{AgNO} 35.0 \mathrm{mg} / \mathrm{L}+$ Calcium pantothenic $2.0 \mathrm{mg} / \mathrm{L}+$ L2 vitamin. The other twenty-two media failed to induce shoot formation, and calli became brownish and finally died. Thus, addition of BAP and GA3 and supplemented with L2vitamin in specific ratio induced shoot formation (Fig. 2)

This study showed that shoots could be regenerated from calli derived from cotyledon, first leaf, hypocotyl, and epicotyl. Each callus produced up to four shoots in eight days after transferred into regeneration medium. Calli were transferred to new medium if no shoots produced in two weeks after regeneration. Calli appeared on MS + BAP 1.0 $\mathrm{mg} / \mathrm{L}+\mathrm{GA} 32.0 \mathrm{mg} / \mathrm{L}, \mathrm{AgNO} 35.0 \mathrm{mg} / \mathrm{L}+$ Calcium pantothenic $2.0 \mathrm{mg} / \mathrm{L}+\mathrm{L} 2$ vitamin could be caused by the optimum ratio of auxin and cytokinine in media. Besides, $\mathrm{AgNO}_{3}$ is known to improve regeneration frequency [23]. 
Higher cytokinine concentration than auxin tends to promote bud formation. On the other hand, higher auxin concentration than cytokinine led to promote root formation. This mechanism, however, did not take place in a simple manner, but in fact, specific external growth regulators and their ratio supplemented in media interacting with the endogenous hormones existing in explant. Different with a study from [19], the axillary shoot-tip explants proliferated to produce the maximum number of shoot buds on a medium containing 5-10 mg/L BAP alone or in combination with 1 mg/L IAA. According to [13] MS media supplemented with $4.0 \mathrm{mg} / \mathrm{L}$ BAP was the best shoot regeneration from callus.

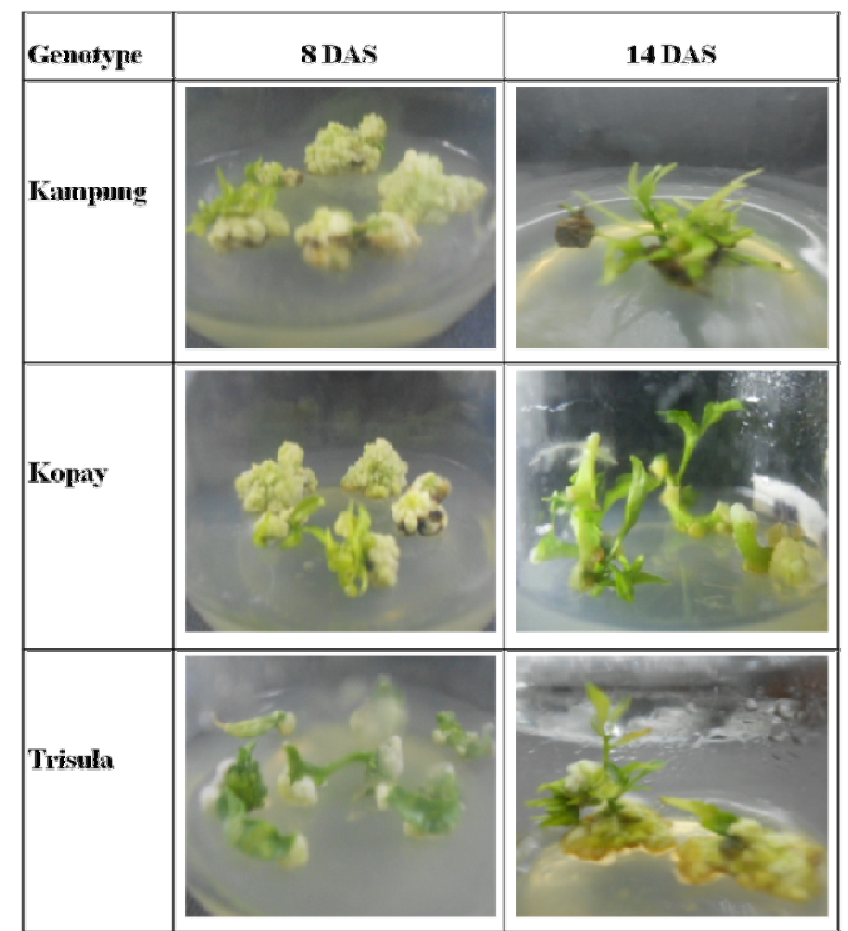

Fig. 2 Development of calli to shoots of three genotypes of chili on MS+BAP $1.0 \mathrm{mg} / \mathrm{L}+\mathrm{GA} 32.0 \mathrm{mg} / \mathrm{L}+\mathrm{AgNO} 35.0 \mathrm{mg} / \mathrm{L}+$ Calcium pantothenic $2.0 \mathrm{mg} / \mathrm{L}+\mathrm{L} 2$ vitamin

\section{J. Root Induction}

Eighteen medium combinations were used for root induction. Four media mainly consisted of MS and WPM supplemented with NAA, sucrose and L2 vitamin could successfully promote root induction. Meanwhile, fourteen medium combinations failed to promote root induction. Medium with WPM + NAA $0.4 \mathrm{mg} / \mathrm{L}$ showed fastest root regeneration compared to the others and could promote root regeneration in two weeks after shoots have been transferred to the rooting medium. Medium WPM + NAA $0.2 \mathrm{mg} / \mathrm{L}$, and MS+NAA $0.15 \mathrm{mg} / \mathrm{L}+\mathrm{L} 2$ vitamin, MS+NAA $0.1 \mathrm{mg} / \mathrm{L}$ + L2 vitamin almost showed similar result.

Rooting was an important step in tissue culture. Rooting could be stimulated by administration of growth regulators. The commonly used growth regulator in tissue culture belongs to auxin groups, such as IAA, IBA, and NAA [25]. Data showed that roots grew in all four media (MS and WPM) were initiated from the base of calli, followed by root elongation. Detail analysis showed that roots grown in WPM based medium (WPM + NAA $0.2 \mathrm{mg} / \mathrm{L}$ and $\mathrm{WPM}+\mathrm{NAA}$
$0.4 \mathrm{mg} / \mathrm{L}$ ) produced more roots than MS-based medium (MS + NAA $0.15 \mathrm{mg} / \mathrm{L}$ + L2 vitamin, and MS + NAA $0.1 \mathrm{mg} / \mathrm{L}$ + L2 vitamin) (Fig. 3). This was caused by four kinds of media that might be more appropriate to produce roots than any other media. The use of NAA with a concentration of 0.1 to $0.4 \mathrm{ppm}$ could stimulate the formation of calli. In contrast [15] used only a half of MS basal medium containing $1 \mathrm{mg} / \mathrm{L}$ IBA. While [12] used MS supplemented with $0.1 \mathrm{mg} / \mathrm{L} \mathrm{NAA}+0.05 \mathrm{mg} / \mathrm{L}$ IBA for rooting of chili. While [11] used MS without growth regulator for rooting of Capsicum annuum 'Hivita Red' and 'Hivita Yellow'.

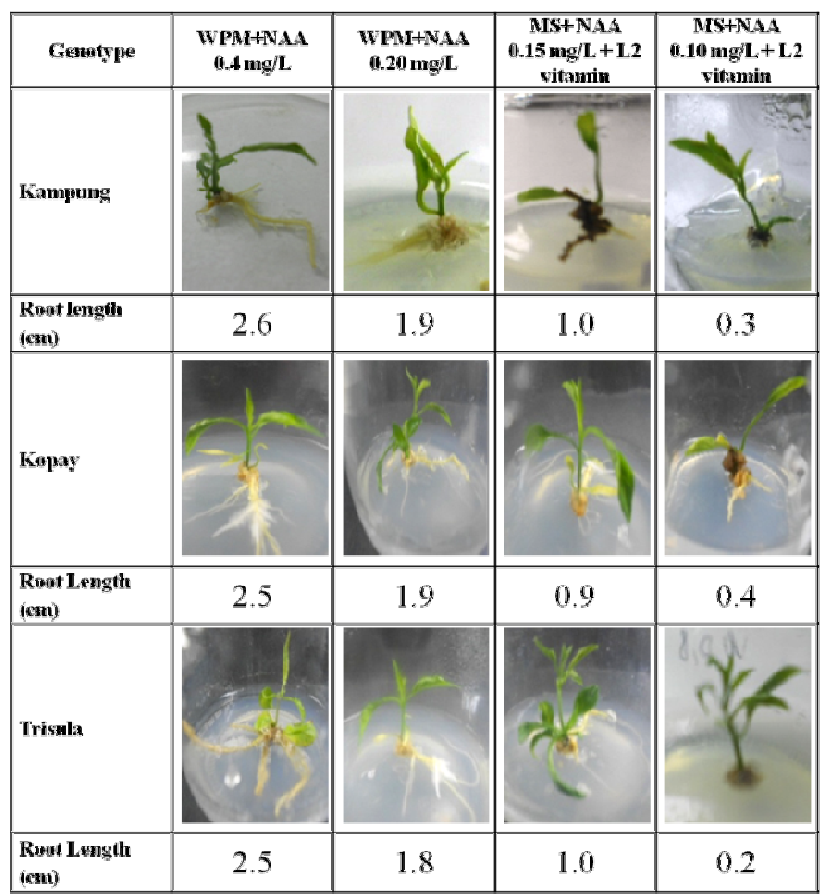

Fig. 3 Representative of root induction from three different genotypes growth in four different rooting medium

The longest roots was resulted on WPM + NAA $0.4 \mathrm{mg} / \mathrm{L}$, $\mathrm{WPM}+\mathrm{NAA} 0.2 \mathrm{mg} / \mathrm{L}, \mathrm{MS}+\mathrm{NAA} 0.15 \mathrm{mg} / \mathrm{L}+\mathrm{L} 2$ vitamin, and $\mathrm{MS}+\mathrm{NAA} 0.1 \mathrm{mg} / \mathrm{L}+\mathrm{L} 2$ vitamin), respectively for three genotypes chili. The response of three genotypes was similar for the four types of media used. Calli were always formed at the base of the stem and followed by the emergence of roots. This was presumably due to the presence of cytokinins in shoots. Auxin interacted to form calli first, to the next forming roots. Ref. [20] reported by that proliferated shoot buds also showed rooting and elongation on medium containing $0.5 \mathrm{mgL}^{-1}$ IBA. Several studies also reported the higher effectiveness of NAA in inducing rhizogenesis of the regenerated shoots in Capsicum [26]-[27].

It is assumed that root formation for all three genotypes was optimum with the auxin derived from NAA in a range of concentration from 0.1 to $0.4 \mathrm{ppm}$. Cytokinine seemed not essential in this case. But, result from [24], MS+ $5.0 \mathrm{mg} / \mathrm{L}$ $\mathrm{NAA}+0.1 \mathrm{mg} / \mathrm{L}$ Kinetin showed the good response for root induction which is also still in line with [28] for sweet potato. On the other hand, lower concentration of NAA $(0.1$ $\mathrm{mg} / \mathrm{L})$ could efficiently promote rooting in Orostachys fimbriata [29] 


\section{CONCLUSION}

In vitro regeneration system of three local cultivars chili pepper Kopay, Kampung and Trisula could be optimized from cotyledon, first leaves, hypocotyl, and epicotyl. The best medium to induce calli formation was MS containing BAP $4 \mathrm{mg} / \mathrm{L}$, IAA $0.5 \mathrm{mg} / \mathrm{L}$ and L2 vitamin (Thiamin- $\mathrm{HCl}$ and Pyrodoxine $\mathrm{HCl}$ ) + sucrose $30 \mathrm{~g} / \mathrm{L}+$ plant agar $8.0 \mathrm{~g} / \mathrm{L}$, with $5.8 \mathrm{pH}$. While, the best medium to induce and elongate shoots was MS containing BAP $1.0 \mathrm{mg} / \mathrm{L}+\mathrm{AgNO} 35.0$ $\mathrm{mg} / \mathrm{L}+\mathrm{GA} 32.0 \mathrm{mg} / \mathrm{L}+$ Calcium pantothenic $2.0 \mathrm{mg} / \mathrm{L}+$ L2 vitamin. The best medium to root induction is WPM medium supplemented with NAA $0.4 \mathrm{mg} / \mathrm{L}$

\section{ACKNOWLEDGEMENT}

This research was fully funded by Directorate General of Higher Education, Ministry of Research, Technology and Higher Education of Indonesia via some schemes. Part of data in this manuscript was generated via the scheme of the National Strategic Grants, while some data was prepared via Scheme of Professorship Cluster Research Grant for the fiscal year 2016, contract number: 524/XIV/A/UNAND2016.

\section{REFERENCES}

[1] P.W. Bosland and E.J. Votava, "Peppers: Vegetables and spice capsicums. Crop Production science in Horticulture," CAB Internasional Publishing Wallingford, England, U.K, 2000, vol. 12.

[2] A.K. De, "Capsicum: The Genus Capsicum. Medicinal and Aromatic Plants-Industrial Profiles," Taylor \& Francis, London and New York, 2003

[3] A. J. De Lucca, S. Boue, M.S. Palmgren, K. Maskos, and T.E.. Cleveland, "Fungicidal properties of two saponins from Capsicum frustenscens and the relationship of structure," Can. J. Microbiol., vol. 52, pp. 336-342, April. 2006. doi:10.1139/W05-137.

[4] P.H.K. Ngai and T.B. Ng, "A lectin with antifungal and mitogenic activities from red cluster pepper (Capsicum frutescens) seeds," Appl. Microbiol. Biotech., vol. 74, pp. 366-371, Feb. 2007. DOI: 10.1007/s00253-006-0685-y.

[5] J. Jamsari and J. Pedri, "Complete nucleotide sequence of DNA Alike genome and DNA- $\beta$ of monopartite pepper yellow leaf curl virus, a dominant begomovirus infecting Capsicum annuum in West Sumatera Indonesia," Asian Journal of Plant Pathology, vol. 7: pp. 114. 2013. DOI: 10.3923/ajppaj.2013.1.14

[6] J. Jamsari, I. Ferita, A. Noverta, E. D. Husada, F. W. Herberg, W. Nellen, L. Syukriani, "A pathogenic isolate of monopartite PepYLCV DNA A-like genome differs significantly in $\mathrm{C} 1$ gene and CR sequence, but not in their other genes," Plant Pathol. J., vol. 15, pp. 124-134, Sept. 2016. DOI: 10.3923/ppj.2016.

[7] I.B. Ahmad, M.N. Hanina, A.M. Mahir, and A. Zaiton, "Transformation of red chilli variety Cilibangi-2 (Capsicum annum L.) with cDNA of cucumber mosaic virus coat protein gene by direct uptake," Pakistan Journal of Biological Science.vol. 5, pp. 683-687, 2002. DOI: $10.3923 /$ pjbs.2002.683.687

[8] J. Gubis, Z. Lajchova, J. Farago, Z. Jurekova, "Effect of genotipe and eksplant type on shoot regeneration in tomato (Lycopersicon esculentum Mill)" in-vitro," Czech J. Genet. Plant Breed, vol, 39, pp. 9-14, 2003

[9] S. Kintzios, J.B. Drossopoulos, E. Shortsianitis, and D. Peppes, "Induction of somatic embryogenesis from young, fully expanded leaves of chilli pepper (C.annuum L.): effect of leaf position, illumination and explants pretreatment with high cytokinin concentration," Scientia Horticulturae, vol. 85, pp. 137-144. July. 2000. http://dx.doi.org/10.1016/S0304-4238(99)00135-1

[10] Renfiyeni, Yusniwati, J. Trisno and Jamsari, "Calli induction of some chilli pepper (Capsicum annuum L.) genotypes as material for genetic transformation," International Journal of Agricultural Science. Vol. 1, pp. 75-80. 2015.
[11] J.Y. Song, I. Sivanesan, C.G. An and B.R. Jeong, "Adventitious shoot regeneration from leaf explant of miniature paprika (Capsicum annuum) 'Hivita Red' and 'Hivita Yellow'. African Journal of Biotechnology, vol. 9, pp. 2768-2773, April. 2010.

[12] Yusniwati, "Drought Tolerant Transgenic strains of chili with P5CS Genes Encoding Key Enzyme Biosynthesis Proline: Regeneration and Characterization of regenerants," PhD. Dissertation Graduate School of Bogor Agricultural University. 2008.

[13] M. Ashrafuzzaman, M.M., Hosain, M.R., Ismail, M.S., Haque, S.M. Shahidullah and S.U., Zaman, "Regeneration potential of seedling explants of chili (Capsicum annuum)". African Journal of Biotechnology, vol, 8. pp. 591-596. January 2009.

[14] I. Mariska, S. Hutami, M. Kusmiatin, A. Husni, W.H. Adil, Y Supriyati, "Somatic embryogenesis in different soybean varieties". Proc. of workshop on soybean biotechnology for Al tolerant in acid soils and disease resistance. Central Research Institute for Food Crops Biotechnology Bogor, 2001. p: 34-45.

[15] R. Hasnat, N.A. Abbasi, T. Ahmad, and I.A. Hafiz, "Induction and regeneration of hypocotyl derived calli in hot chilli (Capsicum frustenscens L.) varieties". Pak. J. Bot., vol. 39, pp. 1787-1795, 2007.

[16] O.A. Kumar, S.S, Tata, and T. Rupavati, "In vitro induction of callusogenesis in chili peppers (Capsicum Annuum L.)", International Journal of Current Research, vol. 3, pp. 042-045. April 2010 .

[17] V. Kumar, H.B. Gururaj, B.C.N. Prasad, P. Giridar and G.A. Ravishankar, "Direct shoot organogenesis on shoot apex from seedling explants of Capsicum annuum L," Sci. Hortic, vol. 106, pp. 237-246, Sept. 2005.

[18] S. Davletova, T. Mészáros, P. Miskolczi, A. Oberschall, K. Török, Z. Magyar, D. Dudits, M. Deák, "Auxin and heatshock activation of a novel member of the calmodulin like domain protein kinase gene families in cultured alfalfa cells," J. Exp. Bot., vol. 52, pp. 215-221, Feb, 2001.

[19] K. Sanatombi, G. J. Sharma, "Micropropagation of Capsicum annuum L," Not. Bot. Hort. Agrobot. Cluj, vol. 35, pp. 57 - 64, 2007.

[20] T. Christopher and M.Y. Rajam, "Effect of genotype, explants and medium on in vitro regeneration of red pepper," Plant Cell Tissue Organ Cult, vol. 46: 245-250. Sept. 1996.

[21] S. Agrawal, N. Chandra, S.L. Kothari, "Plant regeneration in tissue cultures of pepper (Capsicum annuum L. cv. Mathania)," Plant Cell, Tissue Organ Cult, vol., 16, pp. 47-55, Feb. 1989.

[22] I. Manzila, S.H. Hidayat, I. Mariska dan S. Sujiprihati, "Callus induction, Shoot and root regeneration with in vitro culture," Agro Biogen Journal, vol. 6, pp. 65-74. Oct. 2010.

[23] P. Zhang, S. Phansiri and J. Puonti-Kaerias, "Improvement of cassava shoot organogenesis by the use of silver nitrate in vitro," Plant Cell, Tissue Organ Cult., vol. 57, pp. 47 - 54. Oct. 2001.

[24] K. Bodhipadma and D.W.M. Leung, "Histological changes during direct somatic embryogenesis from immature zygotic embryo explants of Capsicum annuum L. cv. Sweet Banana," Phyton (Horn, Austria), vol. 43, pp. 197-206. Jul. 2003.

[25] M. Dąbski and M. Parzymies, "The effect of Auxin: IAA, IBA and NAA on rooting of Hebe buchananii (Hook) and Hebe canterburiensis “(J.B. ARMSTR) PROSTATA In vitro," Acta Sci. vol. 6, pp. 9-14. Feb. 2007.

[26] I. Siddique, and M. Anis, "Thidiazuron induced high frequency shoot bud formation and plant regeneration from cotyledonary node explants in Capsicum annuum," Indian J. Biotechnol, vol. 5, pp. 303308, Jul. 2006.

[27] A. Rakshit, S. Rakshit, A. Deokar and T. Dasgupta, "Effect of different explant and hormones on in vitro callus induction and regeneration of Pepper (Capsicum annuum L.)," Asian J. of Bio Sci. vol. 3, pp. 180-183. March. 2007.

[28] N. C. Onwubiko, C. I. Ihezie and M. U. Mozie, "In vitro regeneration of sweet potato (Ipomea batatas (L.) Lam.) from node explants," AJEA, vol. 8, pp. 87-92. April. 2015.

[29] B. Liu, Y. Zhang, K. Zhang, H. Fang, X. Zhang, X. Qiu, R. Xu, The efficient tissue culture system of Orostachys fimbriata. Agricultural Sciences, vol. 7, pp. 175-180. March, 2016 